\title{
Water Governance in the Asian Highlands
}

Dr Robert Edward Grumbine, Dr Arjumand Nizami, Bikram Rana Tharu, Rabin Niraula, Yufang Su, Dr Jianchu Xu 
$\ldots$

3

$7 x^{2}$
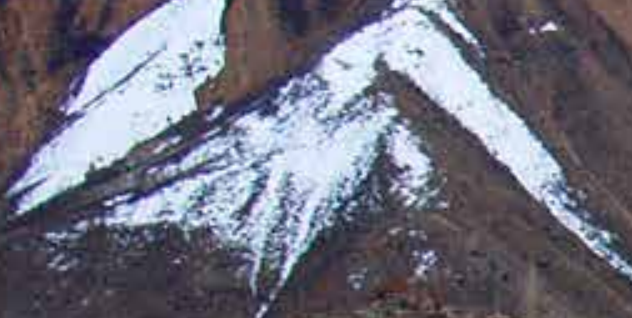

Lestion

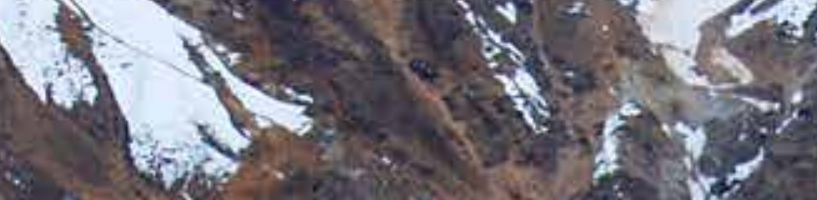

$\frac{x^{2}}{2 x^{2}}$

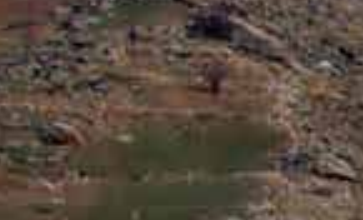

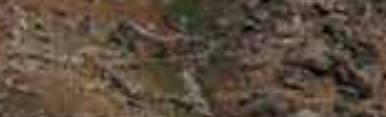

thes

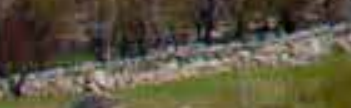

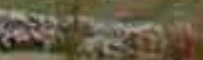

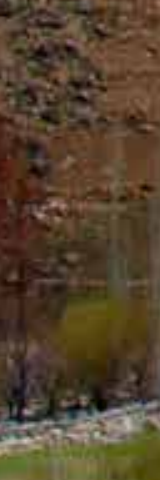

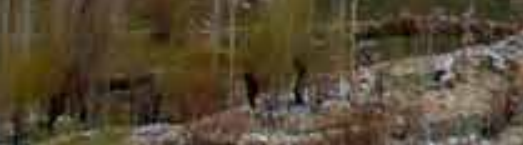

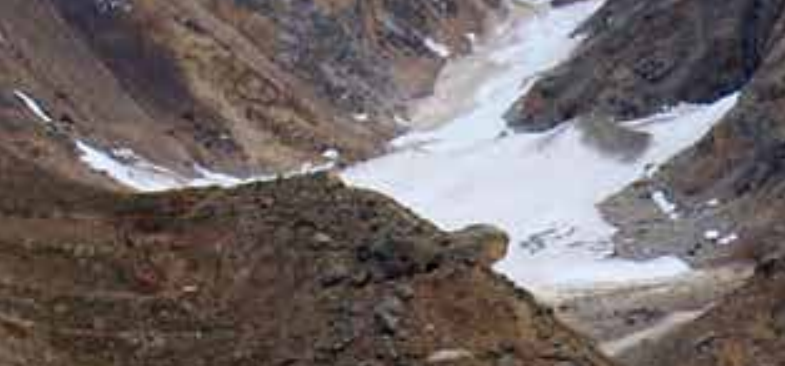

sit-sitisy

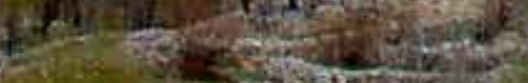

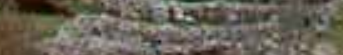

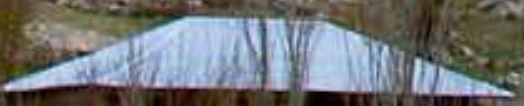

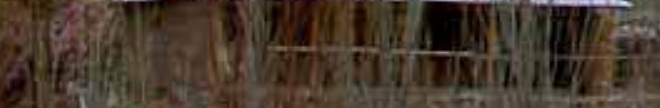

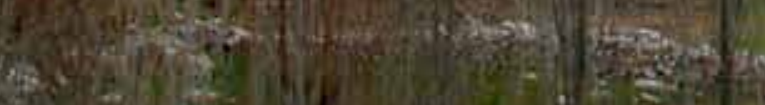

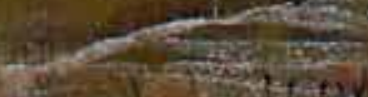

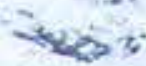

A 12,8

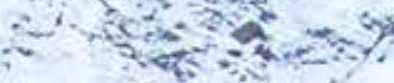




\section{Water Governance in the Asian Highlands}

Dr Robert Edward Grumbine, Dr Arjumand Nizami,

Bikram Rana Tharu, Rabin Niraula, Yufang Su, Dr Jianchu Xu

Working Paper 198 


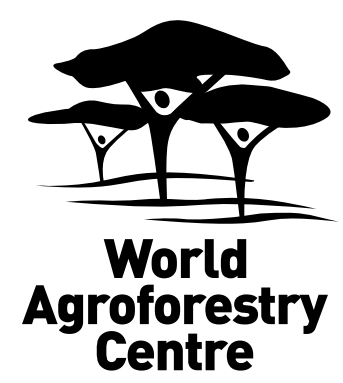

\section{Correct citation:}

Grumbine, R.E.; Nizami, A.; Rana Tharu, B.; Niraula, R.; Su, Y.; Xu, J.C. 2015. Water Governance in the Asian Highlands. ICRAF Working Paper 198. World Agroforestry Centre East and Central Asia, Kunming, China. 25 pp.

\section{DOI: http://dx.doi.org/10.5716/WP15013.PDF}

Titles in the Working Paper Series aim to disseminate interim results on agroforestry research and practices and stimulate feedback from the scientific community. Other publication series from the World Agroforestry Centre include: Agroforestry Perspectives, Technical Manuals and Occasional Papers.

Published by the World Agroforestry Centre

East and Central Asia Regional Programme

\% Kunming Institute of Botany, Chinese Academy of Science

3/F North Research Building

Heilongtan, 650201 Kunming

Yunnan Province, P.R. China

Tel.: +86-871-6522-3014 - Fax: +86-871-6522-3377

Email: icraf-eca@,cgiar.org

Internet: www.worldagroforestry.org/eca

(C) World Agroforestry Centre 2015

Working Paper No. 198

Photos: Asad Kamran, Roshan Ara, Muhammad Asad Salim, Lu Yang

\section{Disclaimer and copyright}

The views expressed in this publication are those of the author(s) and not necessarily those of the World Agroforestry Centre. Articles appearing in this publication may be quoted or reproduced without charge, provided the source is acknowledged. All images remain the sole property of their source and may not be used for any purpose without written permission of the source. 


\section{About the authors}

Dr Robert Edward Grumbine is lead researcher in the Asian Highlands project. He has worked on bringing conservation science into resource management planning and policy. Currently, he is engaged with projects include defining environmental security in China, exploring water governance and hydropower development in the Mekong River Basin and the Himalayas, and improving Chinese biodiversity/protected area management. Grumbine is a senior international scientist at the Kunming Institute of Botany, Chinese Academy of Sciences in Yunnan.

Dr Arjumand Nizami is coordinating community vulnerability and resilience assessments in Pakistan. Currently she works for Helvetas Swiss Intercooperation as the Country Director for Pakistan. Her research interests include access control over natural resources, gender and natural resources, local knowledge, and institutional discourses.

Bikram Rana Tharu is team leader for module-3 of the research project "Building Effective Water Governance in Asian Highlands". He coordinates action research in developing an effective water governance mechanism through dialogue for local water use master planning and to adapt the adverse impact of climate change mainly in the water sector.

$\mathrm{He}$ is the focal person to carry action research on linking local water use master plan of sub-watershed to river basin; under HELVETAS Swiss Intercooperation and ICIMOD collaborative study in the Koshi River Basin Programme of ICIMOD; the study focuses on the relationship between different water use and livelihoods of Koshi basin people.

Rabin Niraula is involved in the Asian Highlands project as a Junior Researcher and enrolled as a $\mathrm{PhD}$ Scholar in Kathmandu University, Nepal. He has a keen interest in GIS applications and working with communities at Grassroot level. He is familiar with ArcGIS, ERDAS, ENVI, eCognition and mapping tools. He was involved in various mapping projects during 2010 - 2012. In 2011 he worked for HELVETAS Swiss Intercooperation and Rights and Resources Initiative (RRI) to research on forest tenure and change in cover. In 2012 he was involved in Riverbed Mapping in HELVETAS Swiss Intercooperation Nepal for River Bed Farming Alliance.

Yufang Su is the deputy director of Centre for Mountain Ecosystem Studies (CMES), a joint centre between Chinese Academy of Sciences and the World Agroforestry Centre, hosted by the Kunming Institute of Botany. She has twenty years research experience in the areas of resource governance, land tenure, rural development, and local adaptation to climate change.

Prof Dr Jianchu Xu is an internationally respected leading ethno-ecologist who works in coupled human environmental systems. His current research includes investigation of early warning signals of global change, trans-boundary water governance, landscape restoration, ecosystem services and their resilience, agriculture, and integrative conservation. Dr Xu leads the World Agroforestry Centre's East and Central Asia regional programme.

\section{Acknowledgement}

The research was part of the IDRC (Canada)-supported project on Building Effective Water Governance in the Asian Highlands. The project aims to build awareness of and preparedness for effective water resource management in the Asian Highlands by encouraging local adaptive livelihood options and improved regional water governance. 


\section{Abstract}

Over the past decade in the Asian Highlands, the pace and magnitude of environmental and social change have been accelerating due to global warming and increasing rates of socio-economic transformation. The effects of change in the Asian Highlands are deepened by the vulnerability of many inhabitants. These factors impact on water governance in the Asian Highlands which is also constrained by gaps between scientific information and policy making. We sought answers to water governance questions at three scales-international, regional, and local. From exploring the published literature, we found clear international consensus on best practices for better water governance, but discovered that few such policies have been adopted in the Asian Highlands. The three countries in our study (China, Nepal and Pakistan) all have strong water laws and strategies on paper, but a mix of political, institutional, and capacity barriers often prevents effective implementation. At the regional level, from published documents and field work, we found striking similarities in both barriers against-and bridges toward-effective water governance. Locally, at our village study sites using household surveys, focus groups, key informant interviews, a water use master planning process with stakeholder dialogues, and a variety of risk and vulnerability analyses, we discovered that while climate and socioeconomic changes are often rapid, governance responses to change have so far been slow. Our research shows that piloting solutions for more effective water governance in the Asian Highlands is more likely to yield success through acknowledging upstream-downstream linkages that create local win-win relationships while building adaptations from the bottom up making use of local hybrid knowledge and science. Given that all Asian Highlands' rivers flow across international borders, the ultimate scaling up issue involves moving water governance from local, district, and regional levels to transboundary water governance for environmental security.

\section{Keywords}

Water Governance, Asian highlands, Climate Change

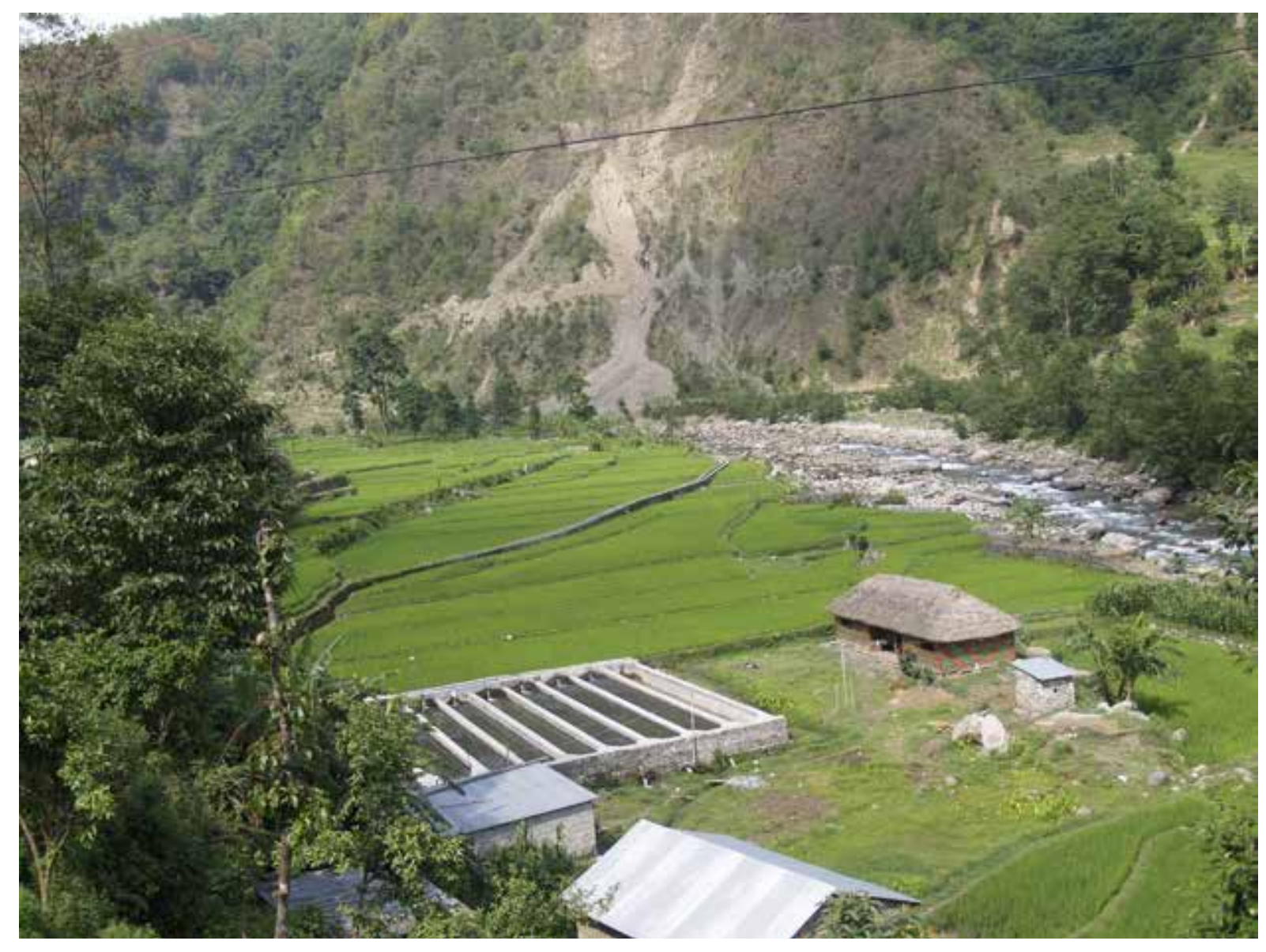




\section{Contents}

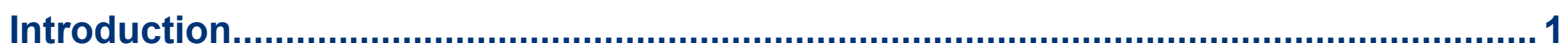

The importance of water governance ............................................................................ 1

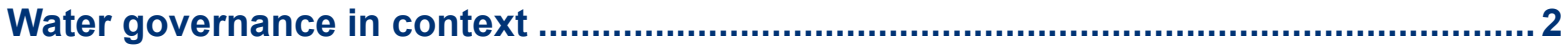

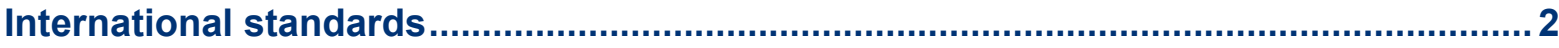

Regional frameworks for water governance ........................................................ 3

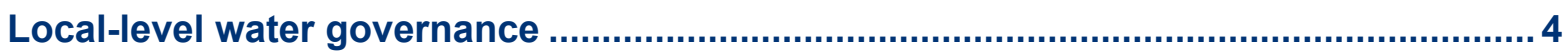

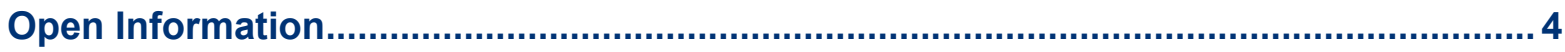

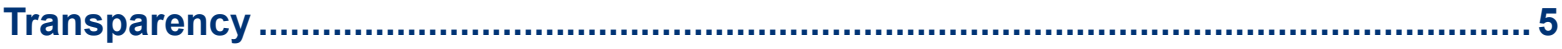

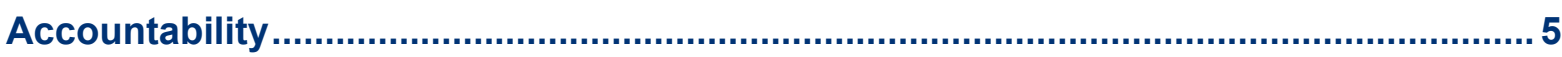

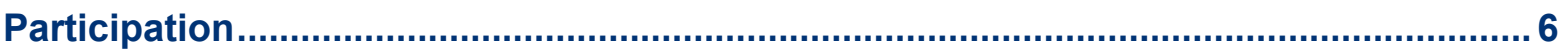

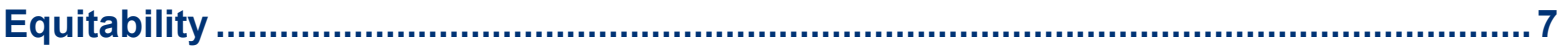

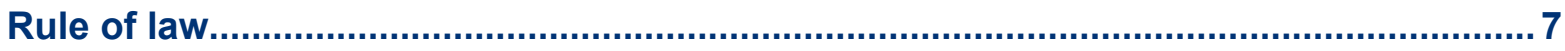

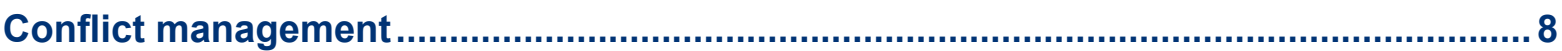

Water governance solutions: local level ...................................................................... 10

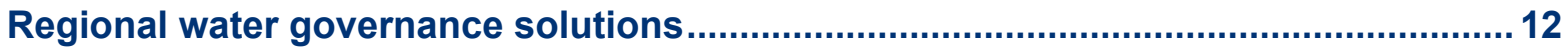

Scaling up to regional transboundary water governance ............................................12

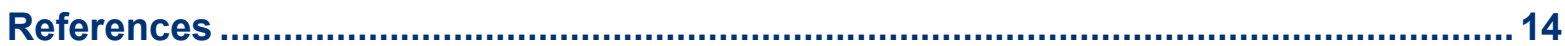




\section{Introduction}

Over the past decade in the Asian Highlands, the pace and magnitude of environmental and social change have been accelerating due to global warming and increasing rates of socio-economic transformation. This region, forming a vast mountainous area above 1000 m.a.s.l. that stretches from the Afghanistan/Pakistan border in the west to Yunnan, China in the east and including the Himalaya massif and Tibetan Plateau, is of global significance. Often referred to as Asia's "Water Tower", the Highlands are the source of most of the major rivers of Asia whose waters sustain about $19 \%$ of the world's people (Pandit et al 2014; Xu et al 2009).

Yet the rate and scale of cumulative change in the Highlands is causing concern. Climate change is already evident; warming in the Himalaya-Tibetan Plateau has been greater than two times the global average (Hijioka et al 2014). Depending on location in the region, projections call for warming to increase by $1.5-3{ }^{\circ} \mathrm{C}$ by $2040-2060$, with greater changes to come by the end of the century (see Zomer et al 2014). In addition to rising temperatures, projections call for more variable precipitation, permafrost degradation, and increasing incidences of extreme events including floods and storms. By mid-century and beyond, these climatic changes may spur unprecedented regional ecosystem "regime shifts" where shrublands replace grasslands and forest species shift to higher elevations (Xu and Grumbine 2014).

Climate impacts combine with development trends to drive change across the Asian Highlands. With Asia booming, governments are supporting more roads, mines, communications, and economic links to outside markets in a region that has been marginalized historically and remains poorly-equipped to manage change. And while Highland dwellers experience opportunities from socioeconomic transformation, developments often suffer from lack of coordinated planning and poor implementation (Gupta 2014).

The effects of change in the Asian Highlands are deepened by the vulnerability of many inhabitants; about half of the 170 million people living in the Highlands are poor (Chaudhary et al 2012).

Although indigenous people have been living in the Highlands for centuries, most states in the region continue to view them as "outsiders;" subjects to be managed rather than full citizens (Scott 2010). Rates of political participation and representation across the region are low. Scholars also note that adaptation behaviours based on local knowledge may be losing their effectiveness; some observers suggest that local climate adaptations may be inadequate to deal with projected future magnitudes of change (Lebel 2012). The consequences are an Asian Highlands that is stratified by political and social inequities, as well as stressed by climate change and poorly managed development.

\section{The importance of water governance}

Water governance comprises: "all social, political, economic, and administrative organizations and institutions..." and "their relationships to water resources development and management" (Tortajada 2010: 299). Water governance addresses equity and efficiency in water resource allocation and distribution; the design and implementation of water policies, laws, and institutions; clarification of the roles of the governments and community institutions; peoples' cultural perceptions and their responsibilities regarding ownership, management, and administration of water resources; stakeholder's participation and conflict resolution; the role of women, men, and underrepresented social groups in water management and more. How water resources and services are governed has a profound impact on people's livelihoods and their sustainable use of water, as well as environmental impacts, yet it is important to remember that water governance is a part of broader social, political and economic developments, and is affected by decisions made well beyond the water sector. 
In other words, water governance is complex, and a major reason for this complexity is that water is not just a natural resource; it is also a political resource (Joy et al 2014). Because of this basic fact, scientific information derived from experts and delivered in a rational framework is insufficient to promote change. Efforts to explicitly link political and social perspectives to water governance analyses using terms like "hydro-solidarity" and the "hydro-social cycle" have yet to attain influence in practice (Pohl et al 2014). Like most places in the world, water governance in the Asian Highlands is constrained by the gaps between scientific information and policy making, as well as by lack of connections between de facto and de jure water management. In addition, differences in attitudes between those regional downstream dwellers who benefit from upstream water and wield greater political power than upstream peoples, must also be accounted for. To take steps toward more effective water governance, one must link scientific information, analyses that recognize the critical roles of power and politics and a knowledge of incentives for change (Araral and Wang 2013; Dore 2014).

With these science/policy gaps in mind in a region where water resources are of paramount importance, how are governments responding to change? Are leaders and institutions pioneering new policies and programs, struggling to adapt to new conditions, or attempting to maintain the status quo? Are countries in the region well-informed about international trends and following best practices in water governance? Are authorities cognizant of indigenous water management practices? If not, what can be done to improve local and regional adaptation to changing conditions going forward? These questions formed the heart of our work in Pakistan, Nepal, and Yunnan, China, as we explored how to build more effective water governance in the Asian Highlands.

\section{Water governance in context}

We sought answers to these water governance questions at three scales-international, regional, and local. From exploring the published literature, we found clear international consensus on best practices for better water governance, but discovered that few such policies have been adopted in the Asian Highlands. At the regional level, from published documents and field work, we found striking similarities in both barriers against-and bridges toward-effective water governance, despite varying conditions between and within countries. Locally, at our village study sites using household surveys, focus groups, key informant interviews, a water use master planning process with stakeholder dialogues, and a variety of risk and vulnerability analyses, we discovered that while climate and socioeconomic changes are often rapid, governance responses to change have so far been slow.

\section{International standards}

Global research reveals a clear consensus on good water governance practices. In reading the published literature, we discovered that a strong international consensus on principles of good water governance has existed for some time (Roger and Hall 2003; Pahl-Wostl et al 2012; UN/ ADB 2012). These principles include: open information exchange; transparency; accountability; inclusive, equitable, and ethical participatory processes; rule of law and conflict resolution. Research has shown that, in general, the more these principles are implemented in a given situation, the better water governance decisions will be for most parties. However, these principles must be recognized as standards and goals; there is no perfect water governance anywhere. Researchers have also found that effective water governance is neutral in terms of political system; that is, these principles should apply in any country at any time. One way to think about "good" water governance is to consider the chances for success when the alternative of each principle is applied (i.e. low levels of open information, little transparency, exclusion of important groups, little/no participation etc.). 


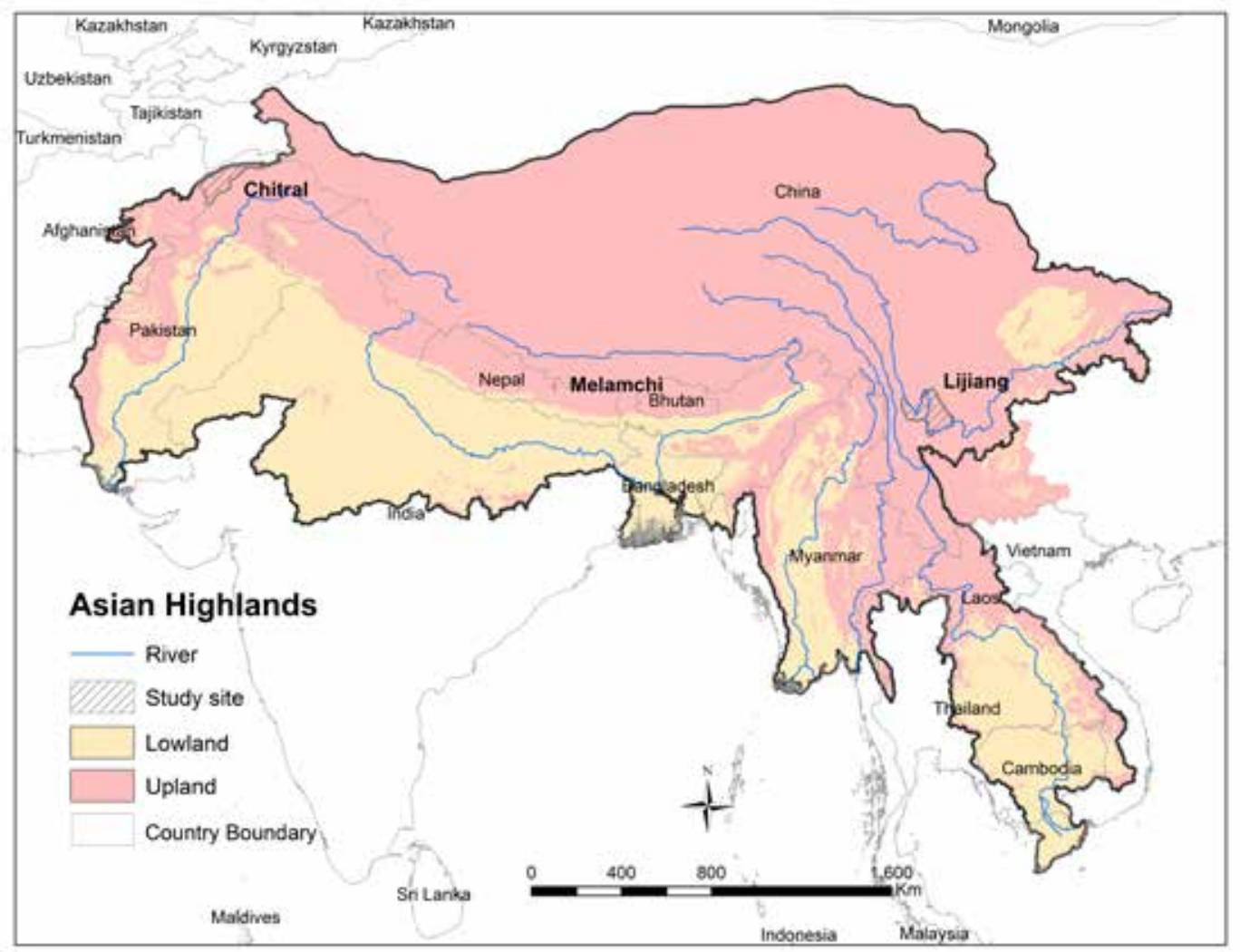

\section{Regional frameworks for water governance}

International water governance standards have had some influence at the regional level in the Asian Highlands through state-level laws and policies. The three countries in our study all have strong water laws and strategies on paper, along with some active projects on the ground. But a mix of political, institutional, and capacity barriers as well as a lack of appreciation of local circumstances often prevents effective implementation.

Pakistan has several pertinent drinking, sanitation, and agricultural water laws (Bisht 2013). The country has also developed a Water Vision 2025 which is guided by demography, technology, social factors, environmental issues, governance, and an increasing role for markets. Yet, there has been very little implementation, and provinces are still reluctant to take the lead to define strategies and policies. It was only in mid-2014 that a first-ever Water Summit discussion was held in Pakistan. Barriers to implementation-fragmented institutions, lack of local participation, little and/or irregular funding, rigid implementation procedures, conflicts within and between customary, provincial and central authorities have been identified in multiple studies (Nadeem et al 2013). These problems result in significant economic costs and impede provincial-level adaptation to both water management and climate change adaptation (Yang et al 2014).

Nepal has a National Water Plan that uses Integrated Water Resource Management as a framework for action. In addition, the country has a National Adaptation Plan of Action (NAPA) linked to local climate action plans that incorporate water issues. Nevertheless, as in Pakistan, there are few implementation plans and little funding, and there are unresolved conflicts between local and central government authority, lack of local knowledge of national planning, unclear land tenure, and almost no integration between central government frameworks and local-level actions. In fact, some authors point out that due to recurrent political upheaval, the government in Nepal is not "coherent or consistent" (Biggs et al 2013). Consequently, actions remain local, and donors support mostly shortterm projects. 
China's strong one-party government is certainly capable of coherent governance and this is reflected in national water laws and policies. Water is owned and managed by the state in a highly centralized, hierarchical manner covering allocation, permits, and fees (Liu and Speed 2009). The principles of IWRM form part of the basis for managing water in China, but there is little coordination between multiple competing ministries, data sharing is limited, bureaucratic barriers abound, and water tenure remains obscure (Yu 2014). Water policies are often simply interpreted as water projects and implemented by a single-line agency. In addition, public participation at any level of politics in China is weak or missing. For example, China's largest water scheme, the South-North Water Transfer project, has almost no room for local people affected by the transfer to provide input (Moore 2015). In fact, to the extent that meaningful participation requires some measure of power sharing, it would be in conflict with government norms and behaviour.

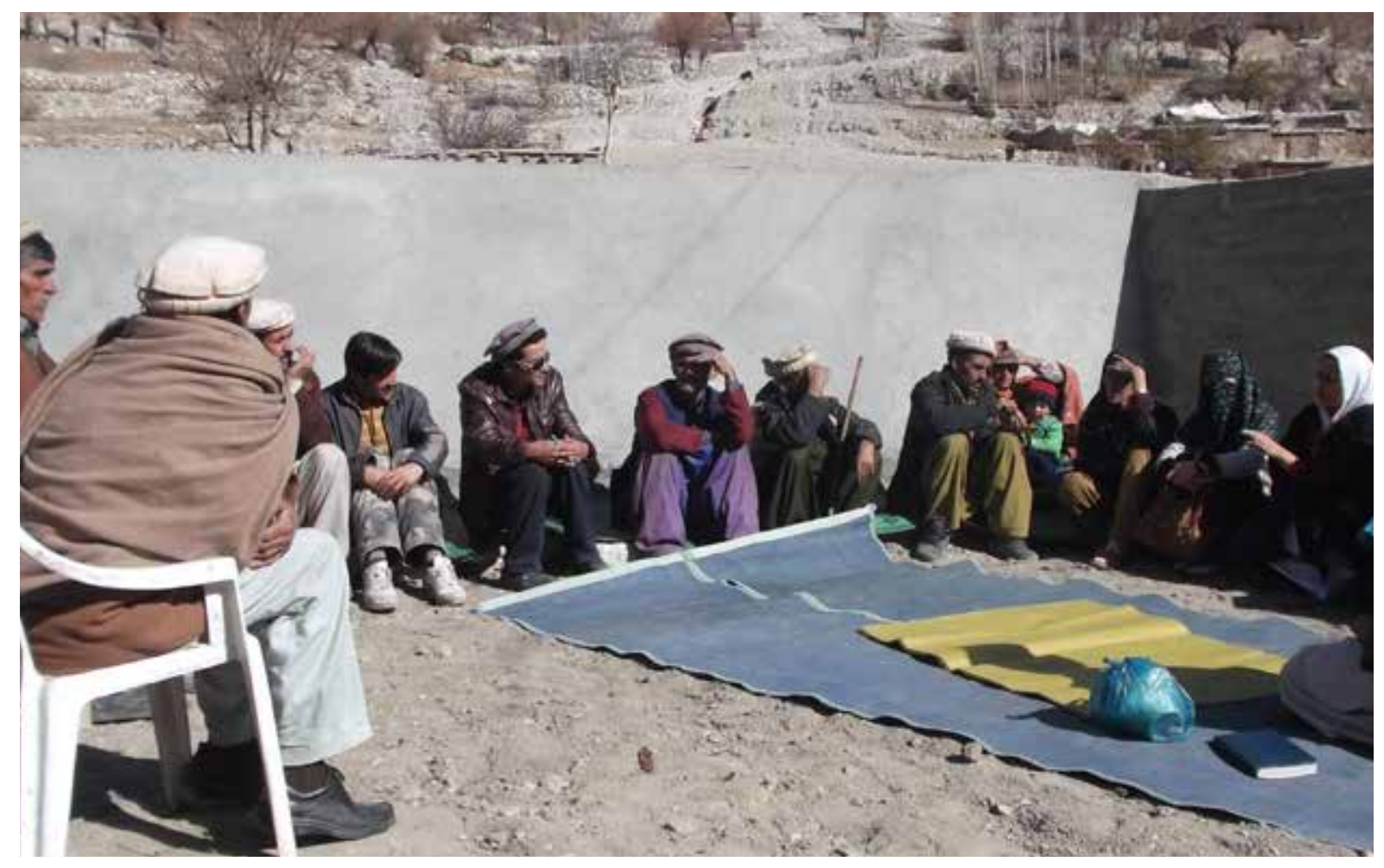

\section{Local-level water governance}

International and regional standards for good water governance have not yet had much influence at the local level in the Asian Highlands. Keyed to each water governance principle from the international consensus, the following analysis is what we found at our three study sites.

\section{Open Information}

A basic tenet of good governance is open sharing of information about specific problems. In all three study sites, we found that such sharing is rare. In Chitral, Pakistan, though villagers directly manage springs and water channels and often share information, there is little contact with district officials. With government action minimal, people are appreciative of NGO support, but in most cases only those who are directly involved may be aware of these projects. We found that lack of knowledge among people, particularly women, about services available from the government is a barrier to finding solutions. Even where government officials want to provide information and services to local people, departments often complain about lack of resources to do this. In Melamchi, Nepal, due 
to lack of education, unclear water tenure rights, and confusing legal provisions information about various water projects is also lacking. The major challenge of open information lies in the lack of technical skills and resources to use information. This limits access of local government to quality information and hinders development projects. While state-led projects are often technically sound, most water project planning at the local level is based on best guesses. There is some information exchange at the user group/Village Development Committee (VDC) level, but there are few mechanisms for people to use to learn about potential water developments. In Lijiang, China, many water projects are implemented, but project funding is often allocated based on personal relations or connections to government officials. Little information on water development is available or exchanged in public or at the local level and it is only shared at the village committee level once decisions have already been made at higher levels of government.

\section{Transparency}

In Chitral, water management happens through three groups: community-customary following tradition, community-modern with NGO support, and the District Government. Decision-making is transparent, but district decisions do not often trickle down to the community. However, communities are strongly-knit together by community-based organizations and these groups' access to leaders provides a platform for better information sharing and transparency. But most government-supported development opportunities occur only after much political effort is expended. In Melamchi, the majority of local people are not often notified about legal decisions, plans, and processes related to state water programs. Program documents and work progress reports are not often made public. There are few established channels for sharing public decisions about water. In Lijiang, people mainly gain knowledge about water actions from village committees and the township administration. Transparency is low; after decades of top-down management, most local people expect not to be involved and only hope the government will provide higher water transfer quotas and compensation fees.

\section{Accountability}

Accountability (responsibility) around decisions about water is problematic at all three sites. In our Chitral study area, most people belong to the Ismaili sect of Islam and have received much support in the past from the Aga Khan Rural Support Programme. In most cases, people consider this group, the Livelihoods Programme, and Water for Livelihoods and other development projects as important for information sharing and accountability. The Livelihoods and Water for Livelihoods programmes have made efforts to bring NGO service providers and communities together. Our household surveys clearly identified the need for better village leader accountability; at the same time, there is a strong belief that the government officials do not feel accountable and also look to donors to lend a hand.

In Melamchi, despite a national self-governance act that promotes downwards accountability on paper, officials appear accountable only towards superiors and donors-and less so to the general public. Officials often form corrupt alliances with outside contractors working on local projects. People are divided based on caste, ethnicity, and political party. Indigenous institutions for water management have eroded; the exception here is Community Forest User Groups who are relatively accountable with the result that forests are in better condition than before. Accountability is centralized in Lijiang, as all decisions are top-down. Local people often look to village leaders, township government, and the water bureau for accountability, but villagers may not be clear about who is responsible for what. Many water projects are named after governmental officials for political reasons and personal promotion. Local people think decision-makers give too much priority to urban/ tourism development. We found no evidence that decision-makers want to have more accountability for their decisions. 


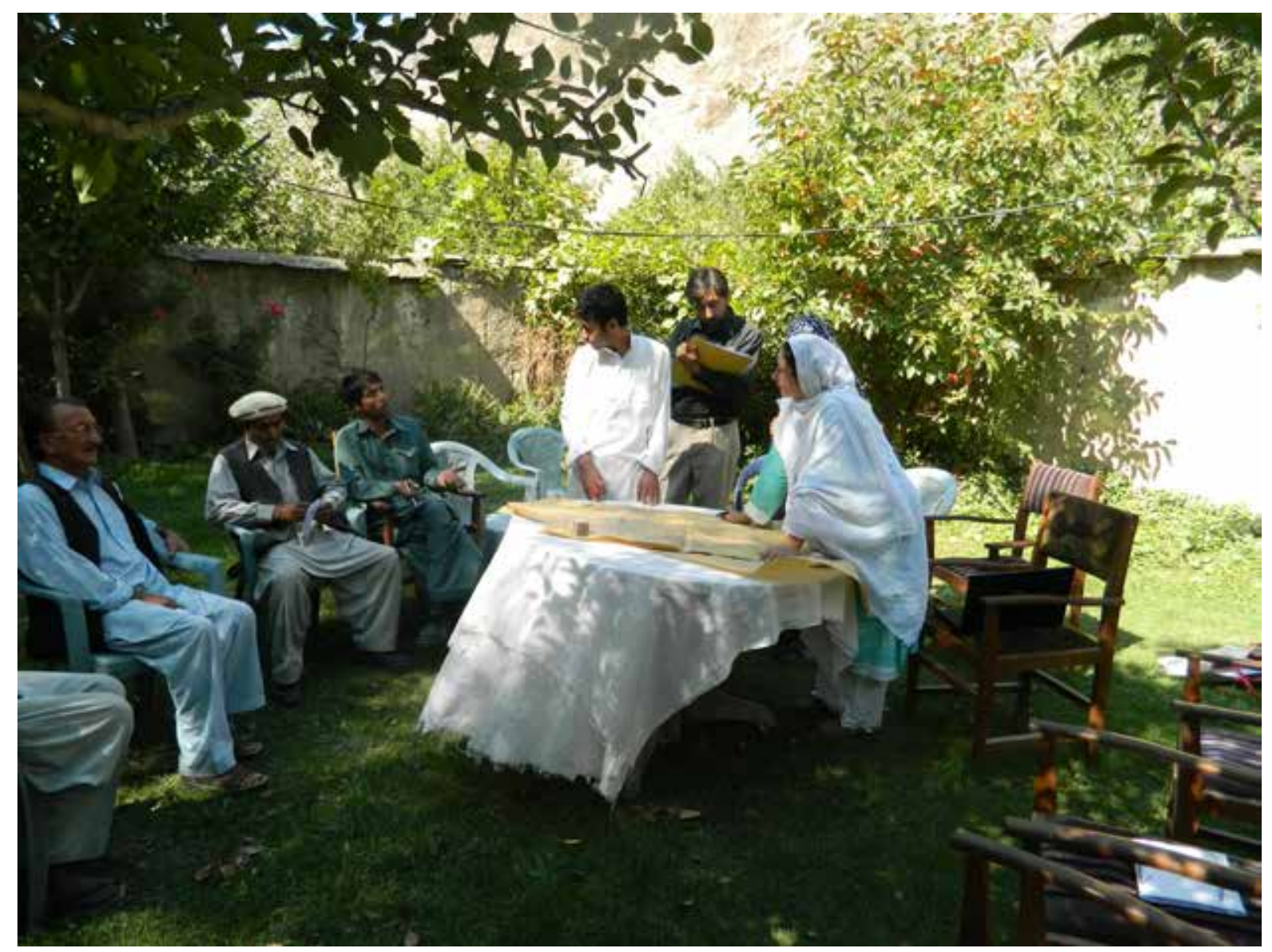

\section{Participation}

Participation at the local level is quite strong and self-evident at the Pakistan and Nepal study sites. In Chitral, people actively participate in water management including annual channel cleaning and financial contributions for repairs. Women seem to be much more active in this regard, since men are often unavailable due to seasonal migration for work. In Melamchi, local communities are very active in defining water use master plans for themselves, get VDC support for implementation, and maintain water structures in a participatory manner. In Lijiang, participation is not so strong.

As far as decision-making and participation in local priority setting is concerned, community participation is generally low across the three study sites. However, participation increases significantly when local communities control their own water projects. Almost half of Chitral community members consider themselves to be in a position to influence the decision making of local leaders. Yet, there is little participation from district officials mainly due to the lack of resources and of mobility to visit remote areas. In Melamchi, decision-making exhibits a lack of interaction and coordination among government, non-government, private sector, and local stakeholders. We also found that participation for disadvantaged groups was lacking where leadership representing such groups was absent. Initiating a water use master planning process in Melamchi was key to building trust through villager participation in mapping critical water sources throughout the study site. However, in all VDCs, we observed that disadvantaged and underrepresented groups had less influence on water decisions. The situation is similar in Lijiang where lack of participation is characteristic of decision-making. Institutionally in China, there are very few channels for community participation in water governance. Villagers want more participation, but from the perspective of local leaders/officials, there is little-to-no-need for this. 


\section{Equitability}

Equity in water distribution is lacking at all three study sites. Conflicts over water distribution are becoming common in Chitral, especially for villages at the tail end of distribution systems which are now in poor shape after installation five to six decades ago. In Melamchi, despite some special provisions to support disadvantaged groups, women, Dalits, Jana Jaits, indigenous people, the poor, and people from remote areas have less representation and access to decision-making. And, for water allocation and use, there are no such special provisions. In Lijiang, while there is plenty of equitability within a given community, there is almost no equitable water governance between levels of political decision-making. Water is transferred and allocated to Lijiang City for urban development and tourism, and compensation to local people is set by officials with no local input. All major crossscale decisions are top-down; even local village leaders are simply informed about what has already been decided.

\section{Rule of law}

Each country in our study has national water laws, but these laws are not often implemented effectively at the local level. Governance is by rules of power, not rule of law. There are local traditional de facto practices and regulations that vary from valley to valley, but there is no evidence from Chitral of any national water law implemented on-site and there is little mediation of water conflicts from any authority. In Nepal, there are many ministries, policies, laws and rules which are in conflict; there is lack of clarity in roles and responsibilities of various agencies and staff. Frequent and sudden changes in policies at the central level make for a confusing working environment for local authorities. Communities still claim that some water resources are private property and they do not want to share them with others. On the other hand, government officials perceive that water is state property. In China, rule of law is poorly recognized and implemented. For example, though deep water wells are illegal, many have been and continue to be constructed by wealthy people and/or highlevel officials.

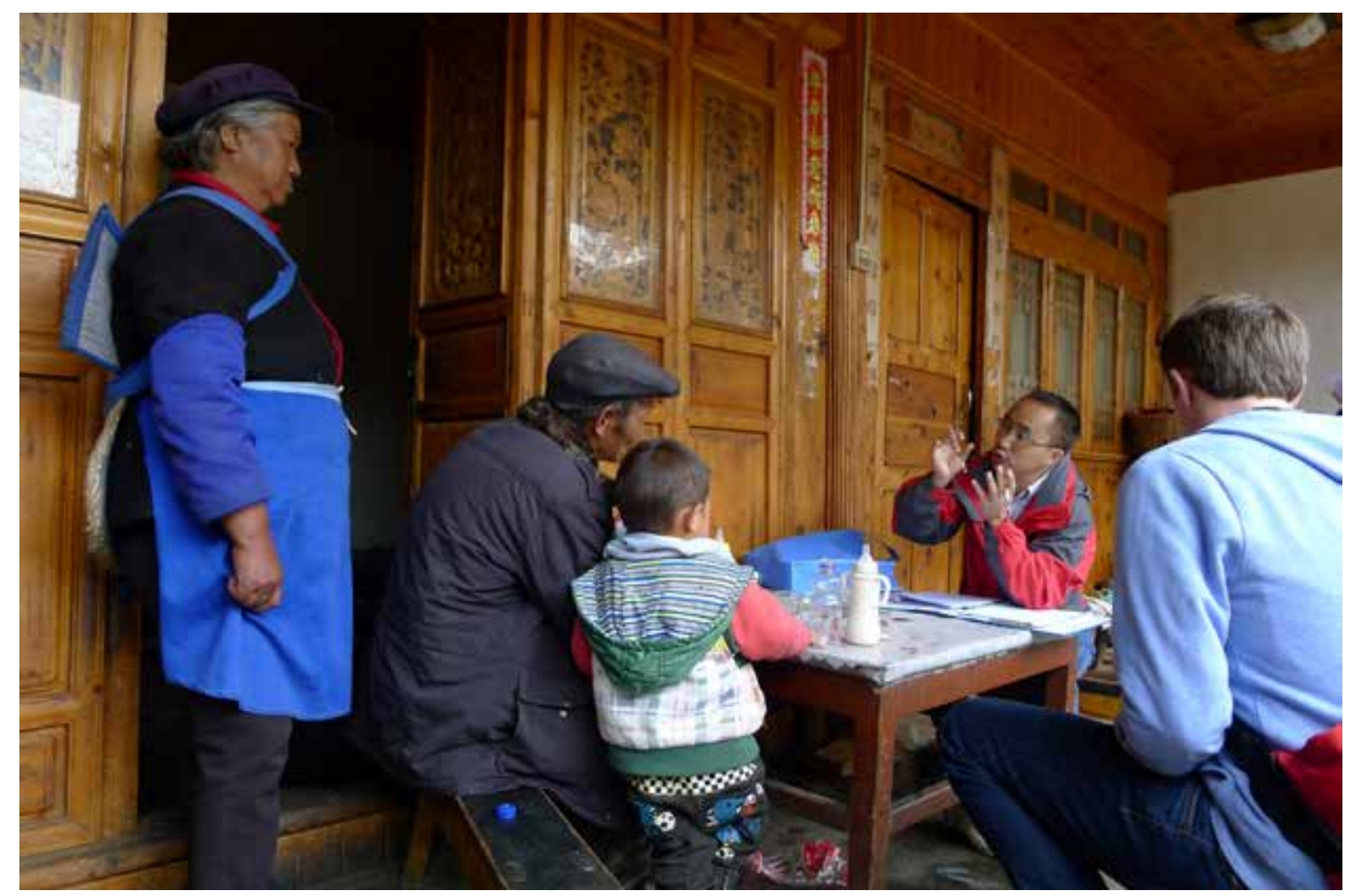




\section{Conflict management}

In Chitral, many people avoid discussion of substantive water issues; conflicts are not often addressed by authorities. Villagers tend to solve conflicts by holding dialogues; people often look up to external NGO mediators. In Melamchi, ownership and use of water sources are areas of conflict. Controversial issues such as allocation and diversion of water to urban centres are rarely solved by local people since decision-making is influenced by a handful of central officials and leaders. In theory, all water sources belong to the state, yet the state has only limited capacity and resources to manage them. In Lijiang, when conflicts over water use arise, villagers and/or village committee leaders are the main managers. If the conflicts cannot be solved at the village, township, district, or city level, local officials step in. However, given the lack of cooperation across agencies responsible for water, issues that demand large-scale (watershed-level) management are difficult to solve in this hierarchical manner.

Evidence from published research and results from our field work are in broad agreement that water governance is weak across the Asian Highlands. While details differ from state to state and locale to locale, common problems are shared widely at regional and local levels. In summary, these include:

- Lack of access to information about water

- Unclear water (and land) tenure

- At all levels, lack of intra- and inter-community dialogue mechanisms (recognizing that the "community" is not a homogenous entity, and that relationships between highland and lowland communities are dynamic and changing)

- Little accountability for decisions by national and regional government

- Low levels of meaningful participation where local people actually influence decisions

- Fundamentally different dynamics between bottom-up and top-down water projects

- Uneven implementation of rule of law due to imbalanced voices and unequal power relationships

- Low system capacity to resolve conflicts

Most of these problems are not amenable to technical, scientific solutions. Due to inequities in political, social, and economic power, local people simply do not have much access to information or decision-making. These issues represent political and social barriers whose resolution requires political influence and timelines that go beyond grant-supported studies. Solutions must take into account actions that stand a chance to be implemented at local and regional levels of government. 


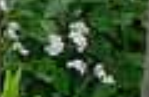

(2).

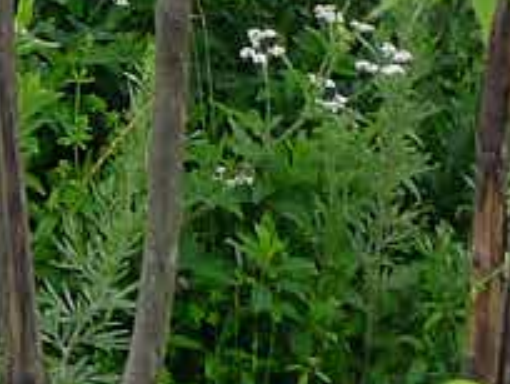

8. 350 .

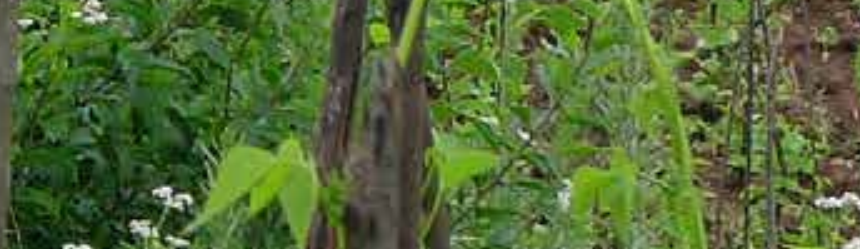
a H. $\sqrt{2}=\frac{40}{40}$ S. 2at 3 -

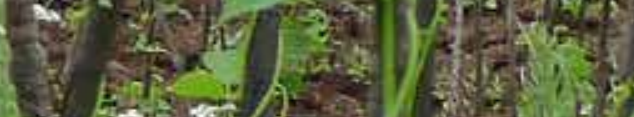

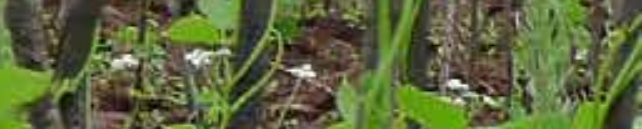

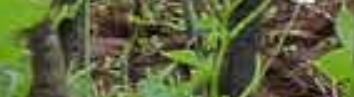

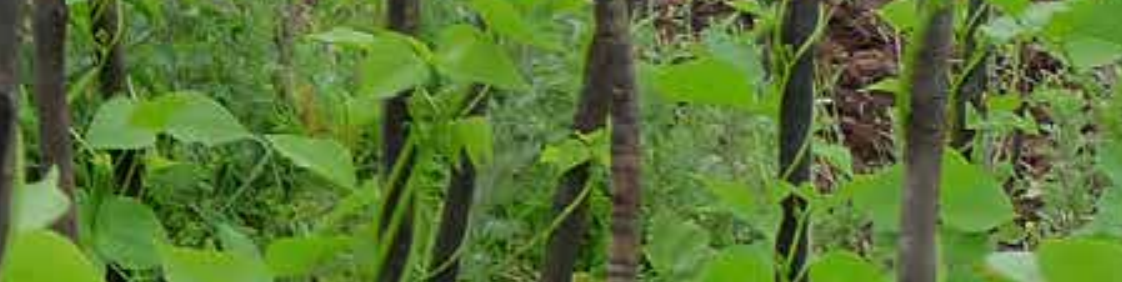
1. $A$ a 


\section{Water governance solutions: local level}

Due to the relative weakness/absence of central state authority in Pakistan and Nepal, local level action provides many potential solutions to water governance issues in the Asian Highlands. Even in China, there are some opportunities to improve water governance through local action. In general, one must promote multi-community, multi-scale, and multi-organizational linkages that bring in new perspectives on water governance and climate change. At the same time, respecting customary water tenure, traditional ecological knowledge, and cultural values are key.

In Chitral, clear understanding of local water rules and assessment of persistent conflicts are entry points to begin local dialogues, especially since water tenure remains vague. Clarifying who owns irrigation channels and who is responsible for maintenance, is necessary; otherwise, people simply wait for development agencies to solve issues.

More support for women is essential since men often migrate in search of cash labour and women are increasingly called upon to look after land-based resources in Chitral. A redesign of conventional agriculture extension services, which are still inclined to serve men, would help women with these responsibilities. More targeted support for farmers who are undergoing climate-related shifts in cropping patterns would also be helpful. High-altitude areas face larger adaptation needs due to more pronounced biophysical changes.

Volunteerism by young people and activists is becoming more important than the services extended by traditional providers. Young people (including young women) are taking lead roles and are more active and educated than their predecessors.

People are pursuing many strategies to adapt to change, but most of these fall under short-term coping vs. long-term adaptation. Most of these measures are led by women for their own households and a few by their close friends and relatives. The government needs to work with villagers to implement the long-term adaptation plans with a focus on collective and/or institutional actions. Given that socially homogenous people live in the study area, this could provide an opportunity for rapid dissemination of new adaptive knowledge. Whatever the means, it is essential for communities to work together so that people can build trust and boost their conflict resolution capacity.

In general, in Melamchi, clarity on water tenure (especially ownership of water) is supposed to be addressed by the national constitution, legislation, and the local Self-governance Act. Rural development planning would improve if water, energy, forests, climate, and disaster risk management were more integrated and participatory. Much of this, however, remains beyond the reach of local efforts and awaits national reforms that create stronger government capacity. We focus here on five areas that can be addressed through local action with limited resources.

1. With as many as three plans often required for every VDC (a Water Use Master Plan, Village Development Periodic Plan (VDPP), and a Local Adaptation Plan of Action focused on climate adaptation), consolidating these efforts into one VDPP-managed process could help integrate planning and support local ownership, equity, and sustainability. But lack of information, very low technical skills and resources for such planning create inefficiencies for VDCs.

2. It is important to understand where incentives exist within the local power structure where elites might be willing to relinquish decision-making power. Championing effective VDC planning that meets central government "minimum condition performance measures" is one incentive that could lead to increased funding. 
3. Water Use Master Planning has served well as a dialogue and negotiation platform engaging local people with their knowledge of water sources and embedding them into the VDC political and funding processes. However, the very low technical skills and resources for such planning create inefficiencies for VDCs; herein lie the main opportunities to improve water governance. Expanding this program to other VDCs will take more support and funding; a first step would be to work with adjacent areas in a cluster approach. Currently, the national government is considering support for this program, but there remain difficult issues with lack of technical leadership and participation by women and the poor (Rautanen et al 2014).

4. Experimenting with watershed-based planning in some VDCs may provide a better alternative than traditional VDC planning since some waters flow across political boundaries.

5. Leadership needs to continue to focus on trust building and a rights-based approach that triggers local empowerment, participation by the poor, women, and marginalized people, and provision of socio-economic benefits to local people.

In Lijiang, while the current government appears to be little interested in moving away from highly- centralized water management, local people are buffered from immediate negative impacts of change due to relatively high household incomes, government financial support, and technical capacity (Zheng et al 2014). Yet, government transparency, along with people's participation in decision-making, are very low. Right now, there are few leverage points to build more effective water governance. The city water bureau, flush with funding from Beijing and the Provincial government, is mostly interested in infrastructure construction and technology improvement. To make progress, it may be better to work with the provincial and municipal financial departments which provide monies to the water bureau. With their potential contributions to increasing economic performance, disaster relief, risk reduction, and efficient technological improvements offer paths to engage the state around water management.

Despite the rampant competition that results in lack of administrative coordination in China, a focus on the positive economic benefits of bundling tourism development with plans for revitalizing agriculture and diversifying local livelihoods could initiate change ( $\mathrm{Su}$ et al in press; Zheng and Byg 2014). There also may be room for change around climate policy; according to the national-level Vice Minister of Water Resources, China is adopting new approaches to deal with climate/water issues. These policies include: improved water allocation; more integrated water management; accelerating the construction of water diversion projects; developing more hydropower; and the general promotion of science and technology for more efficient water usage. But these solutions are mostly technological and do little to address issues of participation and institutional capacity for better water governance.

It would be helpful if the government understood how allowing open information exchange and more local citizen leadership could be of value. Work at other locations in China (Guo et al 2014) has shown that change toward good water governance is stimulated when supportive leaders are operating on at least two administrative levels. Yet, paradoxically, while the current government shows less interest in a transition toward more participatory water governance than officials in Nepal and Pakistan, the nature of politics in China is such that change can occur relatively quickly and funding and technical capacity are not barriers to reform as they are at the other study sites. 


\section{Regional water governance solutions}

Our research shows that piloting solutions for more effective water governance in the Asian Highlands is more likely to yield success through acknowledging upstream-downstream linkages that create local win-win relationships while building adaptations from the bottom up making use of local hybrid knowledge and science. Working at higher levels of government appears to be more intractable: in Pakistan and Nepal, the state is relatively weak resulting in too many institutional disconnects between policy making and on-the-ground implementation, while in China's strong state system, there exist few avenues to influence officials above the village level. This looks to be especially problematic with groundwater where almost nothing has been done anywhere in the Highlands to address growing problems (Famiglietti 2014). Government behaviour appears to be in direct conflict with empirical evidence showing that states that can best implement adaptive management for water and for climate change will likely be more successful at adapting to the resource limits and uncertainty projected for the $21^{\text {st }}$ century (ADB 2014). Will Asian Highlands states be willing and able to reframe their governance systems to meet the challenges of 1) mitigating impacts from water (and other) resource stresses; and 2) building adaptive capacity into current governance? More specific to our work, how can success at the local level be scaled up beyond a handful of pilot projects?

The clearest answer to this last question comes from Nepal. With water use master planning increasingly embedded in VDCs in Melamchi (and several other areas of the country), the national government is actively debating how to increase support. We have designed a strategy to extend planning to nearby VDCs in the same river basin, but government approval requires us to wait before this work can be undertaken. This illustrates a critical problem with weak links between local and national water action everywhere in the Highlands: success at the local level can be stymied by a loss of momentum while officials deliberate and/or funding is secured. Nepal's local climate action planning (LAPA) illustrates this problem. Though Nepal was the first country to adopt a LAPA (2011), these documents contain few sound adaptation measures and little implementation has occurred. Unstable government is one reason for this slow response. Another reason is funding; only about half of monies needed have been committed. Even if $100 \%$ funding were available, its distribution would likely overwhelm the local VDC offices; in Nepal, VDC budgets top out at 30,000 USD/year while low-end cost estimates for LAPA implementation/VDC/year are 200,000 USD (Chaudery et al 2014).

In Pakistan, water use master plans engaged villagers and the district government with high levels of ownership, though paying for these plans remains a problem. Yet these plans have contributed to a continuous dialogue among stakeholders on sharing responsibilities and resolving conflicts. Across the Asian Highlands into the mid-term future, scaling up local successes must take weak and poor government processes into account or work will likely fizzle out.

\section{Scaling up to regional transboundary water governance}

Given that all Asian Highlands' rivers flow across international borders, the ultimate scaling up issue involves moving water governance from local, district, and regional levels to transboundary water governance for environmental security (Grumbine 2014; Molden et al 2014; Rasul 2014). The preponderance of evidence shows that river basin environmental security is undermined by states that have not (yet) bought into the benefits of adaptive governance and efficient management for their own people, let alone for transboundary objectives. There is increasing constructive engagement in the neighbouring Mekong Basin countries to tie together water, food, and energy planning, but in the Highlands, incentives for change are not strong enough to tip the balance away from the national "state-first" status quo. Only the Indus River has benefitted from transboundary water 
policy implementation (Yang et al 2014). At some point, however, environmental security for Asian Highlands nations cannot be supported under conditions of closed information, less transparency, inefficient institutional coordination, and reduced participation from those people who are most affected by water governance decisions. A recent ADB report echoes what we discovered in our field work, calling on states to build capacity for water scarcity and climate change adaptation by investing in community-level vulnerability assessments, supporting livelihood diversification, and creating channels for local people to participate in decision-making (ADB 2014). Yet, given what these new policies might mean for development goals and power relations within and between Highland governments, near-term implementation of such recommendations is uncertain.

Addressing constraints on transboundary water-adaptive behaviour in the Asian Highlands requires several steps. First, one must understand where individual states are positioned on incentives to cooperate, support for local participation, open information exchange (internally and with other nation-states), and other good governance characteristics. International donors and NGOs have not always done this, seeing institutional and legal fragmentation as rooted in a lack of "capacity" rather than as a consequence of explicit state development goals and strategies (Suhardiman and Giordano 2014).

Second, one must evaluate strategies for better governance through the power relationships, institutional capacities, and development visions that drive each Highland country. Research that does not account for unruly politics and institutional disincentives to change is unlikely to influence decision-makers. New research shows that in numerous global river basins, government regime and legal system characteristics are more important than level of economic development in predicting whether states are amenable to experimenting with international standards of water governance (Bernauer and Bohmeht 2014).

Third, one needs to communicate research results in a clear, culturally-sensitive manner to a variety of audiences: local people, leaders, donors, NGOs, and scientists (Ross and Berkes 2013). Better water governance is not just about open communication; it involves good communication among multiple actors.

In the Asian Highlands, Integrated River Basin Management has been the standard bearer for building more effective water governance. However, a limitation of this approach is that it does not highlight the politics behind decision-making (Gain, et al, 2013). It may be better to emphasize general holistic systems thinking as long as it captures the values and politics embedded in decisions around water. An environmental security approach, on the other hand, focuses on managing ecosystem, economic, political, and social risks that can undercut state stability under changing conditions. This may be a better method at capturing the attention of governments' intent on maintaining power (Cui, 2013; Grumbine, 2014). Finally, a focus on security may also help to showcase the importance of coordinated action across sectors for mutual economic benefits. After all, most Asia Highlands countries share broad growth and development goals, and water governance and environmental objectives need to be hitched to what drives less-developed states' behaviour. 


\section{References}

ADB. 2014. Climate Change and Rural Communities in the Greater Mekong Sub region: A Framework for Assessing Vulnerability and Adaptation Options. Asian Development Bank, Mandaluyong City, Philippines.

Araral E, Wang Y. 2013. Water governance 2.0: A review and second generation research agenda. Water Resources Management 27: 3945-3957.

Bakker K, Morinville C. 2013. The governance dimension of national security: A review. Philosophical Transactions of the Royal Academy 371: 20130116.

Bernauer T, Bohmeht T. 2014. Predicting international river basin conflict and cooperation. Global Environmental Politics 14: 135-144.

Biggs E, Tompkins E, Allen J et al 2013. Agricultural adaptation to climate change: observations for the Mid-Hills of Nepal. Climate and Development 5: 165-173.

Bisht M. 2013. Water Sector in Pakistan. Policy, Politics, Management. ISDA Monograph series No. 18. Institute for Defense Studies and Analyses, New Delhi.

Chaudhury AS, Sova CA, Rasheed T et al 2014. Deconstructing Local Adaptation Plans for Action (LAPAs) - Analysis of Nepal and Pakistan LAPA Initiatives. Working Paper No. 67. CGIAR Research Program on Climate Change, Agriculture and Food Security. Copenhagen, Denmark. Available online at: www.ccafs.cgiar.org

Chaudhary P, Thapa K, Lamsal K, Tiwari P, Chhetri N. 2012. Community-based climate change adaptation for building local resilience in the Himalayas. In Tech.

Cui S, 2013. Beyond history: non-traditional security cooperation and the construction of Northeast Asian international society. Journal of Contemporary China 22 (83) 868-886.

Dore J. 2014. An agenda for deliberative water governance arenas in the Mekong. Water Policy 16: 194-214.

Famiglietti JS. 2014. The global groundwater water crisis. Nature Climate Change 4: 945-948.

Gain AK, Rouillard JJ, Benson D, 2013. Can integrated water resources management increase adaptive capacity to climate change adaptation? A critical review. Journal of Water Resource Protection 5: 11-20.

Grumbine RE. 2014. Assessing environmental security in China. Frontiers in Ecology and the Environment 12: 403-411.

Guo J. 2014. Learning through international cooperation: a case study of two Chinese counties implementing the Grain for Green project. Asia Pacific Journal of Public Administration 36: 201210.

Gupta KM. 2014. Climate change and looming crisis over Tibetan Plateau. Journal of Indian Research 2: 137-145. 
Hijioka, Y., E. Lin, J.J. Pereira, et al, 2014: Asia. In: Climate Change 2014: Impacts, Adaptation, and Vulnerability. Part B: Regional Aspects. Contribution of Working Group II to the Fifth Assessment Report of the Intergovernmental Panel on Climate Change [Barros, V.R., C.B. Field, D.J. Dokken, M.D. Mastrandrea, K.J. Mach, T.E. Bilir, M. Chatterjee, K.L. Ebi, Y.O. Estrada, R.C. Genova, B. Girma, E.S. Kissel, A.N. Levy, S. MacCracken, P.R. Mastrandrea, and L.L. White (eds.)]. Cambridge University Press, Cambridge, United Kingdom and New York, NY, USA, pp. 13271370.

Joy KJ, Kulkarni S, Roth D, Zwarteveen M. 2014. Re-politicizing water governance: exploring water re-allocations in terms of justice. International Journal of Justice and Sustainability 19: 954-973.

Lebel L. 2012. Local knowledge and adaptation to climate change in natural resource-based societies of the Asia- Pacific. Mitigation and Adaptation Strategies Global Change.

Liu B, Speed R. 2009. Water resources management in the People's Republic of China. Water Resources Development 25: 193-208.

Moore SM. 2015. Modernization, authoritarianism, and the environment: the politics of China's South-North Water Transfer Project. Environmental Politics 23: 947-964.

Molden DJ, Vaidya RA, Shrestha AB, Rasul G, Shrestha MS. 2014. Water infrastructure for the Hindu Kush Himalayas. International Journal of Water Resources Development 30: 60-77.

Nadeem S, Younis M, Ahmed F. 2013. Policy and Institutions in Adaptation to Climate Change: Case Study on Responding to Water Stress in Chitral, Pakistan. ICIMOD Working Paper 2013/2. ICIMOD, Kathmandu.

Pahl-Wostl C, Conca K, Kramer A, Maestu J, Schmidt F. 2013. Missing links in global water governance: a processes-oriented analysis. Ecology and Society 18: 33.

Pahl-Wostl C, Lebel L, Knieper C, Nikitina E. 2012. From applying panaceas to mastering complexity: toward adaptive water governance in river basins. Environmental Science \& Policy 23: 24-34.

Pandit MK, Manish K, Koh LP. 2014. Dancing on the roof of the world: ecological transformation of the Himalayan landscape. BioScience 64: 990-992.

Pohl B et al 2014. The rise of hydro-diplomacy. Berlin: Adelphi, German Federal Foreign Office.

Rasul G. 2014. Why Eastern Himalayan countries should cooperate in transboundary water resource management. Water Policy 16: 19-38.

Rautanen S-L, van Koppen B, Wagle N. 2014. Community-driven multiple use water services: Lessons learned by the rural village water resources management project in Nepal. Water Alternatives 7: 160-177.

Roger P, Hall AW. 2003. Effective Water Governance. TEC background paper, No. 7. Global Water Partnership, Stockholm. 
Ross H, Berkes F. 2013. Community resilience: toward an integrated approach. Society and Natural Resources 26: 5-20.

Scott J. 2010. The Art of Not Being Governed: An Anarchist History of Upland Southeast Asia. New Haven, CT: Yale University Press.

$\mathrm{Su}$ Y, Hammond J, Villamor G, et al in press. The impacts of tourist development on rural livelihoods in Lijiang, southwest China: Increasing success or vulnerability? Water International Journal.

Suhardiman D, Giordano M. 2014. Legal plurality: An analysis of power interplay in Mekong hydropower. Annals of the Association of American Geographers 104: 973-988.

Tortajada C. 2010. Water governance: some critical issues. International Journal of Water Resources Development 26: 297-307.

UN/ADB, 2012. Green Growth, Resources and Resilience. Environmental Sustainability in Asia and the Pacific. United Nations and Asian Development Bank. Bangkok, Thailand.

Xu J, Grumbine RE, Shrestha A, Eriksson M, Yang X, Wang Y, Wilkes A. 2009. The melting Himalayas: cascading effects of climate change on water, biodiversity and livelihoods. Conservation Biology 23: $520-530$.

Yang Y-CE, Brown C, Yu W et al 2014. Water governance and adaptation to climate change in the Indus River Basin. Journal of Hydrology. In press.

Yu H, Edmunds M, Lora-Wainwright A, Thomas D. 2014. From principles to localized implementation: villagers' experiences of IWRM in the Shiyang River basin, Northwest China. International Journal of Water Resources Management 30: 588-604.

Zheng Y, Byg A, Thorsen BJ, Strange N. 2014. A temporal dimension of household vulnerability in three rural communities in Lijiang, China. Human Ecology 42: 283-295.

Zheng Y, Byg A. 2014. Coping with climate change: households' response strategies to drought and hailstorm in Lijiang, China. Environmental Hazards 4: 211-228.

Zomer RJ, Trabucco A, Metzger M et al 2014. Projected climate change impacts on spatial distribution of bioclimatic zones and ecoregions within the Kailash Sacred Landscape of China, India, and Nepal. Climatic Change 25: 445-460. 
The World Agroforestry Centre is an autonomous, non-profit research organization whose vision is a rural transformation in the developing world as smallholder households increase their use of trees in agricultural landscapes to improve food security, nutrition, income, health, shelter, social cohesion, energy resources and environmental sustainability. The Centre generates science-based knowledge about the diverse roles that trees play in agricultural landscapes, and uses its research to advance policies and practices, and their implementation that benefit the poor and the environment. It aims to ensure that all this is achieved by enhancing the quality of its science work, increasing operational efficiency, building and maintaining strong partnerships, accelerating the use and impact of its research, and promoting greater cohesion, interdependence and alignment within the organization.

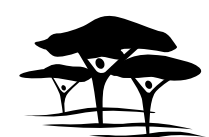

United Nations Avenue, Gigiri • PO Box $30677 \cdot$ Nairobi, $00100 \cdot$ Kenya Telephone: +254207224000 or via USA +16508336645 Fax: +254207224001 or via USA +1 6508336646

Email: worldagroforestry@cgiar.org•www.worldagroforestry.org

East and Central Asia Regional Programme \% Kunming Institute of Botany • 3/F North Research Building Heilongtan • 650201 Kunming • Yunnan Province • P.R. China Telephone: +86-871-6522-3014 • Fax: +86-871-6522-3377 Email: icraf-eca@cgiar.org • www.worldagroforestry.org/eca 